\title{
GUSTAV THUREAU, FIRST TASMANIAN INSPECTOR OF MINES AND GOVERNMENT MINING GEOLOGIST
}

\author{
by G. L. McMullen
}

(with two text-figures, one plate and one table)

\begin{abstract}
McMullen, G.L. 2016 (31:viii): Gustav Thureau, first Tasmanian Inspector of Mines and Government Mining Geologist. Papers and Proceedings of the Royal Society of Tasmania 150(1): 39-43. https://doi.org/10.26749/rstpp.150.1.39 ISSN 0080-4703. Mary Aikenhead Ministries, Bondi Junction, NSW 2022, Australia. Email: gabrielle.mcmullen@maministries.com.au
\end{abstract}

From humble origins as a rebellious student in Clausthal, Germany, Gustav Thureau became the first Tasmanian Inspector of Mines and Government Mining Geologist. He brought to these offices his experience in Germany, South Australia, Victoria and, briefly, America as a miner, mine manager, lecturer, mining inspector, mining reporter and mining consultant. His 50-year career in mining is interspersed with a number of controversies.

Key Words: mining geology, Tasmania, Gustav Thureau.

\section{INTRODUCTION}

A range of peaks southeast of Queenstown in Tasmania is known as the Thureau Hills in acknowledgement of Tasmanian contributions made by Gustav Adolph Hugo Thureau (1831-1901) (pl. 1). Additionally, two Tasmanian fossils were named for him: a fossilised plant that he found at Mount Bischoff (Taxites thureaui Johnston), and the oldest known remains of a vertebrate in Tasmanian rocks which he discovered in the Mersey Coal Measures near Railton (Thureau's Microsaurian, subsequently identified as an eroded cephalopod, M.R. Banks pers. comm. 21 September 1994) (Johnston 1885, 1900-1901). What were Thureau's achievements that accorded him such recognition? These are presented in this paper and summarised in table 1.

\section{GERMAN TRAINING}

Thureau was born in 1831, one of the ten children of Wilhelm Gottlieb Thureau, a brewery administrator, and Dorothee Kreßner; he grew up in the mining town of Clausthal in Germany's Harz Mountains (McMullen 1996). From 1845 he attended the School of Mines attached to the renowned Clausthal Royal Academy of Mines, and trained as a mine foreman (Thureau 1889).

The political unrest of 1848 is generally associated with intellectuals but it was mining student Thureau, at the time the operator of an ore stamper, who led a demonstration at the Rosenhof Mine in August 1848. He was "sentenced to a ten-day prison term for attempting to incite a noisy riot" and left the School of Mines in disgrace - this episode was probably the first indication that Thureau would distinguish himself from those with whom he had grown up and who had had comparable educational opportunities (Oberbergamt [Mining Office] Clausthal-Zellerfeld 1848a).

Following his conviction and resulting unemployment Thureau left Clausthal. He appealed to the local authorities for support and had his passage to Australia funded (Oberbergamt Clausthal-Zellerfeld 1848b). Arriving in Adelaide in March 1849 (The South Australian Register

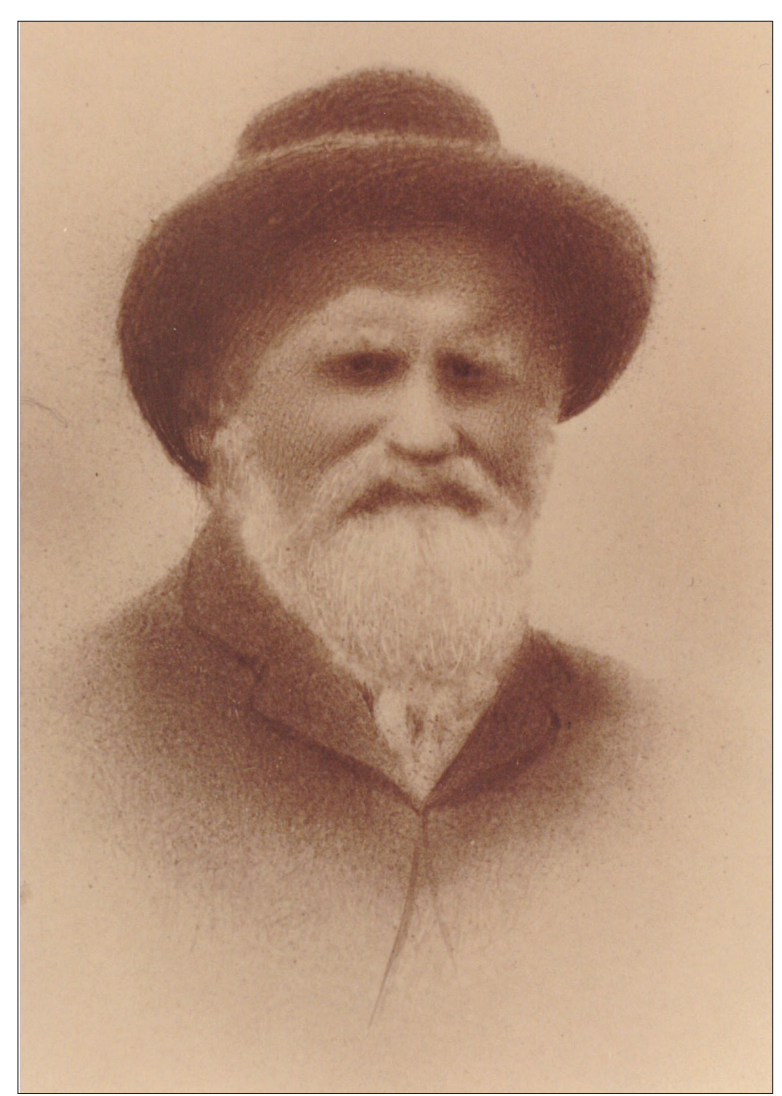

PLATE 1 - Gustav Thureau by Whitelaw of Launceston, from the collection of Mineral Resources Tasmania and reproduced with kind permission.

1849a, b), 17-year-old Thureau worked initially in the Burra Burra copper mines as an ore dresser (The Bendigo Advertiser 1878).

\section{EMERGENCE OF THE MINING GEOLOGIST}

In 1852, like many others, Thureau left for the Victorian goldfields (Victorian Certificate of Naturalisation 1859). 
TABLE 1 - Stages of Gustav Thureau's career

\begin{tabular}{|c|c|c|}
\hline Locations & Years & Career Stages \\
\hline Germany & $1845-1848$ & Royal School of Mines, Clausthal \\
\hline $\begin{array}{l}\text { South } \\
\text { Australia }\end{array}$ & $1849-1852$ & Copper mining at Burra Burra \\
\hline \multirow[t]{4}{*}{ Victoria } & $1852-1872$ & $\begin{array}{l}\text { Miner, mining agent and } \\
\text { mine manager at Forest Creek, } \\
\text { Maryborough, Ararat, Malmsbury, } \\
\text { Taradale, Ballarat, Daylesford, } \\
\text { Warrandyte and St Arnaud }\end{array}$ \\
\hline & $1872-1877$ & $\begin{array}{l}\text { Mining inspector, manager and } \\
\text { reporter (The Bendigo Advertiser) in } \\
\text { Bendigo }\end{array}$ \\
\hline & $1874-1877$ & Lecturer, Bendigo School of Mines \\
\hline & 1875 & Fellow of the Geological Society \\
\hline America & 1877 & Delegate to California and Nevada \\
\hline \multirow[t]{5}{*}{ Tasmania } & 1880 & Consultant mining geologist \\
\hline & 1881 & Consultancy for Government \\
\hline & $1882-1889$ & Inspector of Mines \\
\hline & 1887 & $\begin{array}{l}\text { Addition of title Government } \\
\text { Mining Geologist }\end{array}$ \\
\hline & $1889-1891$ & Private practice \\
\hline \multirow[t]{3}{*}{ Victoria } & $1892-1899$ & Private practice, Melbourne \\
\hline & 1896 & $\begin{array}{l}\text { Member of the Geological Society } \\
\text { of Australasia }\end{array}$ \\
\hline & $1897-1901$ & $\begin{array}{l}\text { Councillor of the Geological } \\
\text { Society of Australasia }\end{array}$ \\
\hline
\end{tabular}

He initially spent five years in Forest Creek as a miner and mining agent. He worked similarly in Maryborough for two years and then Ararat for a year before advancing to the position of mining manager at Malmsbury, Taradale, Ballarat, Daylesford, Warrandyte and St Arnaud (Victorian Certificate of Naturalisation 1859, Public Records Office of Victoria 1865) (see fig. 1). Thus, during his twenties and thirties, Thureau increasingly became an authority on mining and was, on occasions, designated mining engineer. $\mathrm{He}$ also gained a good command of written English and published detailed commentaries on mining - for example, in The Colonial Mining Journal, Railway and Share Gazette (1859, 1861a).

In 1860 Thureau and his colleague Adams discovered the "very promising" Humboldt Reef near Taradale, and the next year they also discovered iron ore in the vicinity (The Colonial Mining Journal, Railway and Share Gazette 1860, 1861b). However, within five years, Thureau was declared insolvent due to losses in mining ventures (Public Records Office of Victoria 1865, Victorian Government Gazette 1865, The Argus 1865). On later occasions Thureau was also in financial difficulties, suggesting a lack of business acumen.

In the early 1870s Thureau moved to Bendigo where he worked as inspector and then as manager of a number of mining companies (The Bendigo Advertiser 1878). He was appointed lecturer in practical engineering at the new Bendigo School of Mines in 1874 and its "first course in geology and mining" is attributed to him (Mackay 1914, Cusack 1973a). The following year Thureau's professional contributions were recognised in his election as a Fellow of the Geological Society of London (Thureau 1889). Significantly, his standing in Bendigo was such that he was selected in 1877 as the "qualified delegate" to go to the United States to report on mining methods there (Thureau 1879). He spent about three months in America and subsequently recommended certain innovations to

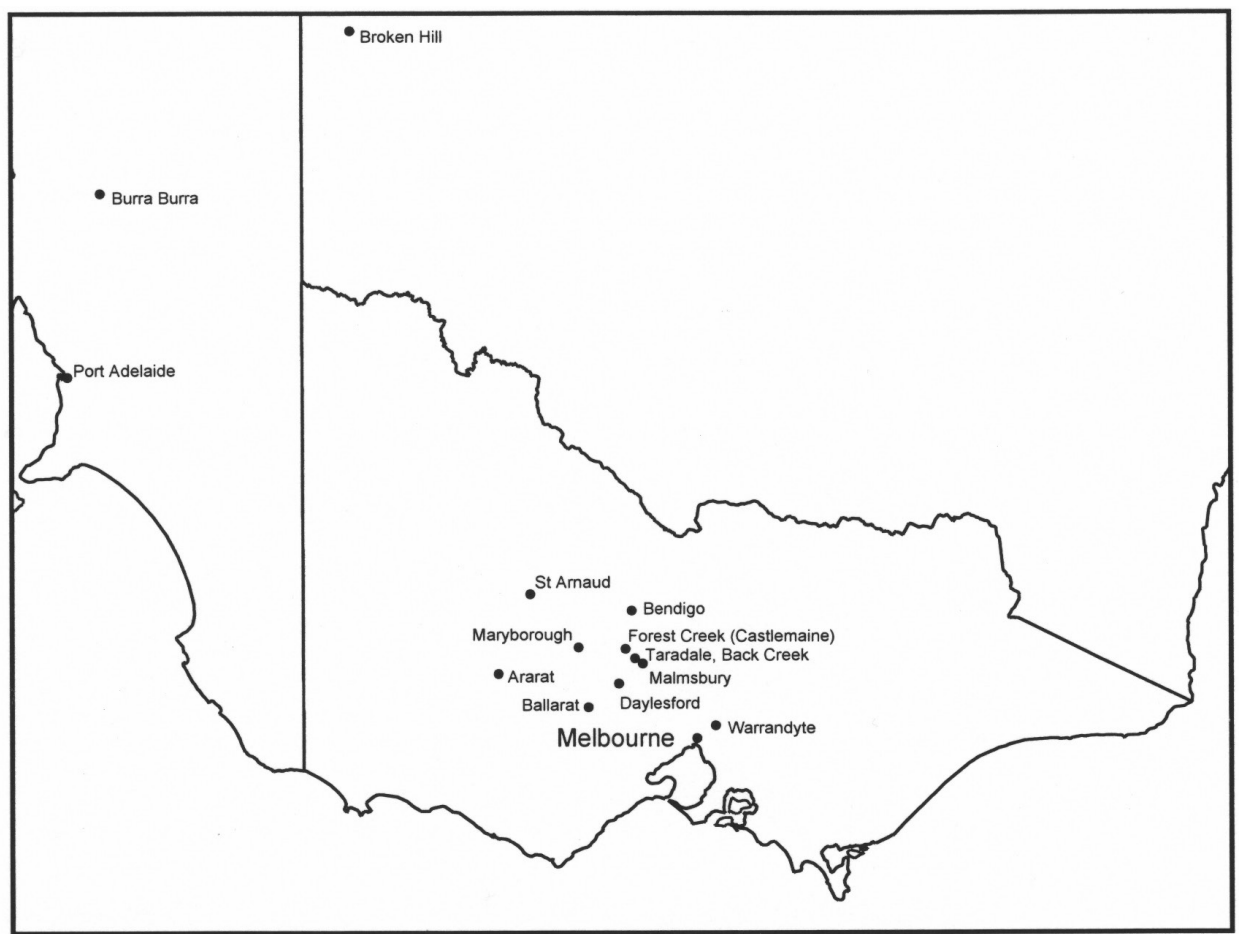

FIG. 1 - Locations on the Australian mainland where Thureau worked. 
improve the efficiency of mining in the Bendigo region. He apparently resigned his lectureship at the School of Mines to accept the American assignment and, upon his return, the School did not have the funds to re-employ him and he was not able to find other work in Bendigo (The Bendigo Advertiser 1878, Cusack 1973b).

\section{TASMANIAN INSPECTOR OF MINES}

In search of new opportunities, in 1880, Thureau went to Tasmania, a decision which initiated a decade of his profound influence on geological surveying and mining in the island state (Certificate of Naturalisation Archives Office of Tasmania [AOT] 1885). Initially, he seems to have earned his livelihood there as a consultant and some of his reports of Tasmanian mines appeared in local newspapers (e.g., The Launceston Examiner 1881). Significantly, he soon had influential connections, including William Ritchie, a key figure in mining investment and a friend of Premier William Giblin.

In 1881 Ritchie suggested to the Premier that Thureau be employed by the Government to report on Tasmania's mineral resources. Thureau was enthusiastic about the consultancy and offered his services at an attractive rate, hoping to secure a permanent appointment (Ritchie 1881). The Premier wrote to Thureau requesting him to inspect and report "upon the various Gold Fields and Tin producing Districts of Tasmania" (Giblin 1881). He noted the difficulty of the assignment in winter but, at the same time, the importance of evaluating local mineral resources. That same year Thureau inspected several districts and wrote extensive reports on their mineral deposits and mines (Thureau 1881a, b).

Following the successful completion of his assignment, Thureau was offered the position of Tasmanian Government Inspector of Mines in 1882 (Inspector of Mines 1882, Bacon 1989). He proposed that, rather than conducting a regular and expensive geological survey with a large and permanent staff, he undertake the work "with a guide or packers" so he could "move quickly" and operate "at very much less expense" (Thureau 1883). Thureau's model was accepted and considered advantageous by the Government (Atkinson 1883).

Upon his appointment, Thureau was 50 years of age and his long association with mining had possibly impaired his health (Thureau 1881a, p. 3; Thureau sent a telegram "asking to be permitted to return to Hobart direct, instead of walking back to Bischoff, which latter I am quite unable to do, as my health has been and is very bad after the wet, fatiguing, and tedious journey"). He was about to undertake a gruelling program of exploration, journeying regularly around the island (see fig. 2). Many mines were in remote and inhospitable regions. Despite the handicaps, he undertook a systematic survey of the state's mineral resources and mines from his base in Launceston and wrote
FIG. 2 - Locations in Tasmania which Thureau inspected, assessed and included in his annual and special reports.

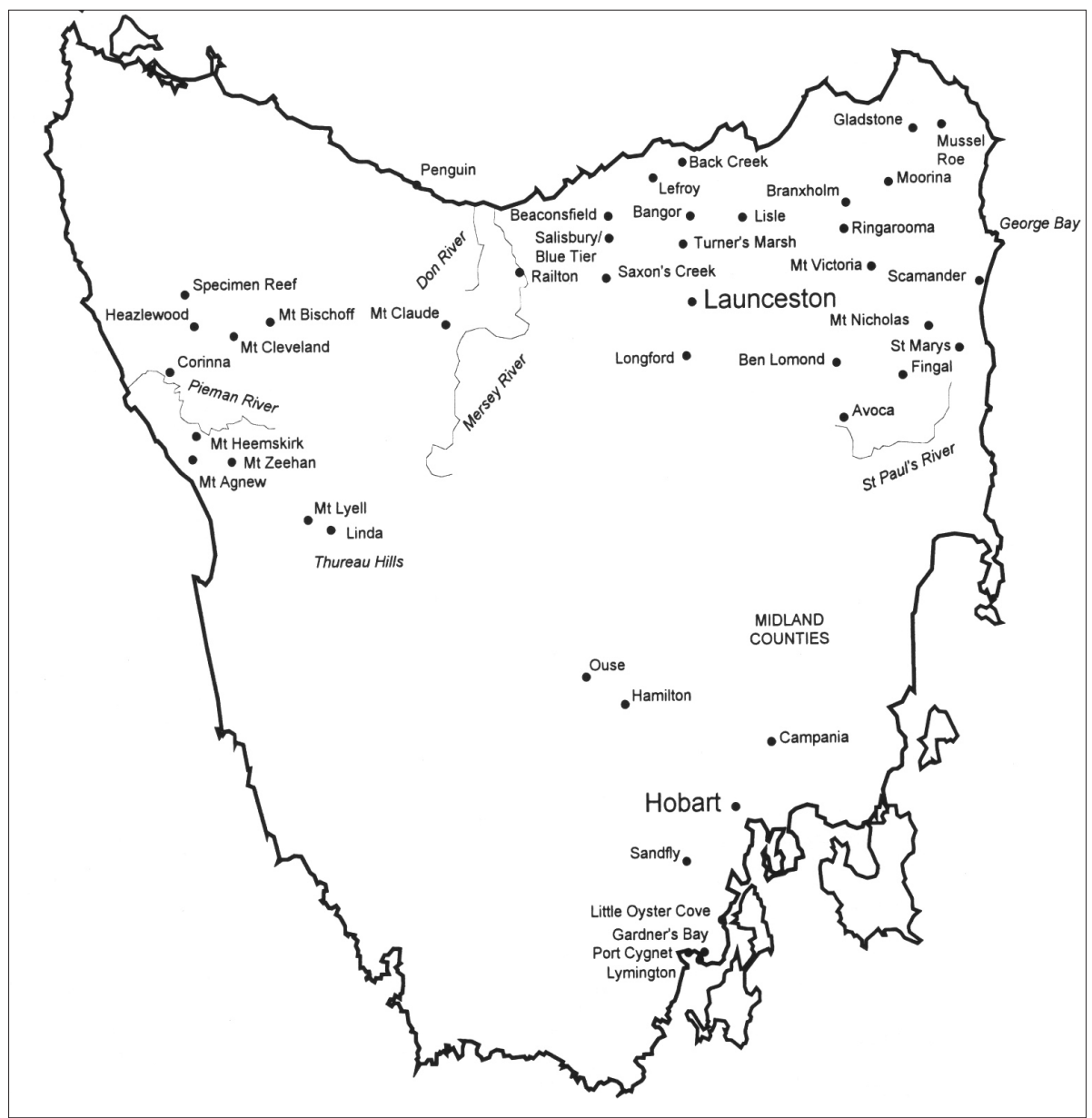


detailed and informative reports. During his expeditions Thureau also recorded illustrated descriptions of the island's geology, resulting in the additional title of Mining Geologist (Secretary of Mines 1887-88, p. 5).

Many of Thureau's assessments of mineral resources were undoubtedly over-optimistic (or only realised much later with improved technologies) and he has been criticised for such reports (Blainey 1969, 1993, Binks 1988). However, he certainly did not anticipate positive outcomes for all districts, and such optimism is typical of contemporary reports (Secretary of Mines 1885, 1887-88, 1888-89, Provis 1888-89). To some degree his failures may be due to the inadequacy of available analyses. However, consultancies for mining companies might, in some instances, have compromised "detached" reports for the Government. Given the climate of speculation surrounding mining, his onerous duties, the strains on his health, friction arising from his Germanic mannerisms, and periodic criticisms of his work as the Inspector of Mines, there were probably occasions when Thureau felt overwhelmed by the pressures of office.

Importantly, Thureau was active both in encouraging Tasmania mining ventures to take advantage of improved technologies and seeking ways to improve the safety standards of its mines (Inspector of Mines 1882, 1883, 1884 , Secretary of Mines 1885, 1887-88, 1888-89). One "miner" wrote in 1884: "Mr. Thureau has won the popularity of the miners ... through having reduced mining accidents almost to nil" (The Hobart Mercury 1884).

Thureau was a Fellow of The Royal Society of Tasmania for several years (The Royal Society of Tasmania 1884). He maintained regular contact with the society and had submissions read at its meetings but, with his residence in Launceston and frequent field trips, it seems that he could only attend meetings infrequently.

In 1885, it seemed that Thureau would be dismissed to save funds in the Mines Branch. He was devastated and requested to remain at a lower cost to the Government (Brown 1885, Thureau 1885). His position was maintained, but his salary and staff were reduced. By late 1888 Thureau's considerable duties had become too much for him. Apart from his advancing age and poor health, Tasmania's mining industry was expanding considerably. Further, it was clear to Thureau that the Government no longer desired his services and in 1889 he asked to resign rather than be dismissed (AOT Letter Book 1888a, 1888b, 1889). There is evidence that Thureau was, in fact, overburdened, in that his successor's duties were to be lightened (Secretary of Mines 1888-89, p. 5).

\section{TWILIGHT YEARS}

Following his resignation, Thureau returned to private practice initially in Launceston and then Melbourne (Blainey 1993, The South Australian Register 1896). He was elected a member of the Geological Society of Australasia in 1896 and subsequently to its Council, probably from 1897-1901 (Geological Society of Australasia 1896-1907). Thureau died in 1901, aged 69 years (The Age 1901).

\section{CONCLUSION}

Australia's nineteenth-century mining industry benefitted from the expertise of German-trained mining men, attracted by Australia's mining prospects - one of these was Gustav Thureau. Given the abrupt disruption of his German training, Thureau had a remarkable career spanning over five decades. In relation to the knowledge of his day, he made an important contribution, particularly to the development of mining geology in Tasmania, where he deserves to be seen as a figure of significance. In praise of Thureau's contribution, Secretary of Mines, Francis Belstead, stated in 1885: "It is beyond dispute that the maintenance in connection with the Department of an officer possessing scientific geological knowledge, is a valuable help to the mining community and will materially aid in the development of an industry" (Secretary of Mines 1885, p. 4).

\section{REFERENCES}

AOT [Archive Office of Tasmania]Letter Book 1888a: AB 872/3 Folio 361-362 4 December 1888.

AOT Letter Book 1888b: AB 872/3 Folio 39517 December 1888. AOT Letter Book 1889: AB 872/3 Folio 4372 April 1889.

Atkinson, T.R. 1883: to Thureau G 15 August 1883 AOT PP $1885 / 101$.

Bacon, C.A. 1989: One Hundred Years of the Department of Mines. Unpublished Report 1989/09 Tasmania Department of Mines, Hobart: pp 1-11.

Binks, C.J. 1988: Pioneers of Tasmania's West Coast. Blubber Head Press, Sandy Bay.

Blainey, G. 1969: The Rush That Never Ended. Melbourne University Press, Melbourne: p 223.

Blainey, G.N. 1993: The Peaks of Lyell. St. David's Park Publishing, Hobart: 370 pp.

Brown, N.J 1885: to Thureau, G. 21 July 1885 AOT PP 1885/101. [Certificate of Naturalisation Archives Office of Tasmania (AOT)]1885: CSD 13/82/167430 April 1885.

Cusack, F. 1973a: Bendigo - A History. William Heinemann, Melbourne: pp. 58, 155.

Cusack, F. 1973b: Canvas to Campus - A History of the Bendigo Institute of Technology. The Hawthorn Press, Melbourne: pp. 54, 58

Geological Society of Australasia 1896-1907: Minute Book for Council and Sub-Committees of Geological Society of Australasia Box 48 Royal Historical Society of Victoria.

Giblin, W.R. 1881: to Thureau, G. 28 April 1881 AOT Min 1/1 File OA/9.

Inspector of Mines 1882: Report of Inspector of Mines for 1882 AOT PP 1883/49.

Inspector of Mines 1883: Report of Inspector of Mines for 1883 AOT PP 1884/60.

Inspector of Mines 1884: Report of Inspector of Mines for 1884 AOT PP 1885/59.

Johnston, R.M.1885: Description of two new species of Tertiary fossil plants belonging to the genera Eucalyptus and Taxites. Papers and Proceedings of the Royal Society of Tasmania 335-336.

Johnston, R.M. 1900-1901: Observations regarding the recent discovery by G. Thureau, F.G.S., of a fossil reptile in the Mersey Coal Measures at Railton. Papers and Proceedings of the Royal Society of Tasmania 9-10.

Mackay, G. 1914: Annals of Bendigo, Vol 2., Mackay \& Co., Bendigo: p. 143.

McMullen, G.L. 1996: "An able practical and scientific man": Gustav Adolph Hugo Thureau, German-trained mining 
geologist. Historical Records of Australian Science 11(2): 149-177.

Oberbergamt [Mining Office] Clausthal-Zellerfeld 1848a: Akte betr. Bergschule Disziplinarsachen 1835-1867 Fach 1854 No 18.

Oberbergamt (Mining Office) Clausthal-Zellerfeld 1848b: Akte betr. Bergschule Disziplinarsachen 1835-1867 Fach 1854 No 5.

Provis, J. 1888-9: Report of 4 August 1889. Report of the Secretary of Mines for $1888-89$ AOT PP $1889 / 81$, pp. 15-18.

Public Records Office of Victoria 1865: VPRS 759/P Proceedings in Insolvent Estates Unit 97 Record 9481 November.

Ritchie, W. 1881: to Giblin, W.R. 20 April 1881 AOT Min 1/1 File OA/9.

Secretary of Mines 1885: Report of the Secretary of Mines, 1885 AOT PP 1886/71.

Secretary of Mines 1887-8: Report of the Secretary of Mines for 1887-88 AOT PP 1888/47.

Secretary of Mines 1888-9: Report of the Secretary of Mines for 1888-89 AOT PP 1889/81).

The Age 1901: 11 March 1901, p. 4

The Argus 1865: 27 November 1865, p. 6.

The Bendigo Advertiser 1878: 23 December 1878, p. 2.

The Colonial Mining Journal, Railway and Share Gazette 1859: 1: 160-161.

The Colonial Mining Journal, Railway and Share Gazette 1860: 2: 101

The Colonial Mining Journal, Railway and Share Gazette 1861a: 3: 89, 104, 118, 153, 166.
The Colonial Mining Journal, Railway and Share Gazette 1861b: 3: 137.

The Hobart Mercury 1884: 17 July 1884, Supplement 1.

The Launceston Examiner 1881: 20 April 1881.

The Royal Society of Tasmania 1884: Report of the Royal Society of Tasmania for the Year 1884, p. 10.

The South Australian Register 1849a: 3 March 1849.

The South Australian Register 1849b: 7 March 1849.

The South Australian Register 1896: 6 November 1896, p. 5.

Thureau, G.1879: Synopsis of a Report on Mining in California and Nevada, U.S.A. Government Printer, Melbourne: pp. 3-5.

Thureau, G. 1881a: West Coast: Progress Reports on Mines by Mr. G. Thureau, FGS AOT PP $1881 / 82$

Thureau, G. 1881b; Ben Lomond and St. Paul's River: Report on Mines by Mr. Thureau, FGS and Port Cygnet, Oyster Cove, and Sandfly: Report on Mines by Mr. Thureau, FGS AOT PP 1881/108 and 109.

Thureau, G. 1883: to Brown, N.J. 10 August 1883 AOT PP $1885 / 101$.

Thureau, G. 1885: to Brown, N.J. 31 July 1885 AOT PP 1885/101.

Thureau, G. 1889: The "Iron Blow" at the Linda Goldfield. Papers and Proceedings of the Royal Society of Tasmania 1-7.

Victoria Certificate of Naturalisation 1859: Register of Patents Book F No 3 Folio 3422 December 1859, p. 406.

Victorian Government Gazette 1865: 1 December 1865, 2799.

(Accepted 3 May 2016) 
